\title{
Drought and leaf damage limit the search for support in the climbing plant Ipomoea purpurea (L.) Roth (Convolvulaceae)
}

\section{La sequía y el daño foliar limitan la búsqueda de soporte en la planta trepadora Ipomoea purpurea (L.) Roth (Convolvulaceae)}

\author{
Cristian Atala ${ }^{1 *}$, Cristian Cordero ${ }^{1} \&$ Ernesto Gianoli ${ }^{2,3,4}$ \\ ${ }^{1}$ Laboratorio de Anatomía y Ecología Funcional de Plantas, Departamento de Ciencia y Tecnología Vegetal, Universidad de \\ Concepción, Campus Los Ángeles, Juan Antonio Coloma 0201, Los Ángeles, Chile. \\ 2Departamento de Botánica, Universidad de Concepción, Casilla 160-C Concepción, Chile. \\ ${ }^{3}$ Departamento de Biología, Universidad de La Serena, Casilla 599 La Serena, Chile. \\ ${ }^{4}$ Center for Advanced Studies in Ecology and Biodiversity (CASEB), Pontificia Universidad Católica de Chile, Alameda 340, \\ Santiago, Chile. \\ *catala@udec.cl
}

\begin{abstract}
There is evidence that some climbing plants increase their twining rate after leaf damage, thus avoiding ground herbivores, and that drought limits this induced response. However, it is unknown whether leaf damage and drought affect the search for support, an ecologically relevant process for climbing plants. We evaluated the combined effect of drought and leaf damage on support searching in the twining vine Ipomoea pupurea (Convolvulaceae). Plants were assigned to a combination of three watering treatments (regular watering, moderate drought, and severe drought) and two damage treatments (control and $50 \%$ defoliation). We placed a stake at $15 \mathrm{~cm}$ from the stem and recorded the time to successful twining (360 $0^{\circ}$ turn). We also measured some plant functional traits to explore possible mechanisms. Leaf damage decreased time to successful twining in all treatments with the exception of severe drought. Severe drought decreased plant growth, particularly when combined with leaf damage. In nature, climbing plants are usually not in contact with a support in the early stages. The searching behavior seems to increase with leaf damage, but it is restricted by water shortage. Plants experiencing both leaf damage and severe drought will be less likely to find a support, resulting in higher probability of further leaf damage.
\end{abstract}

KEYwORDS: Support searching, drought, leaf damage, Ipomoea purpurea.

\section{RESUMEN}

Hay evidencia de que las plantas trepadoras aumentan su tasa de enredo luego del daño foliar, evitando así a los herbívoros, y que la sequía limita esta respuesta. Sin embargo, se desconoce si la combinación del daño foliar y la sequía afectan a la búsqueda de soporte, un proceso ecológicamente relevante para las plantas trepadoras. En este trabajo evaluamos el efecto combinado de la sequía y el daño foliar en búsqueda de soporte en la enredadera Ipomoea pupurea (Convolvulaceae). Las plantas se asignaron a una combinación de tres niveles de riego (riego normal, sequía moderada y sequía intensa) y dos niveles de daño (control y 50\% de defoliación). Se colocó un soporte a $15 \mathrm{~cm}$ del tallo y se registró el tiempo de enredo efectivo (giro de $360^{\circ}$ alrededor del soporte). También se midieron algunos rasgos funcionales para explorar posibles mecanismos. El daño foliar disminuyó el tiempo de enredo efectivo en todos los tratamientos con excepción del de sequía intensa. La sequía intensa disminuyó el crecimiento de las plantas, particularmente al combinarla con daño foliar. En la naturaleza, las plantas trepadoras usualmente no están en contacto con un soporte en sus etapas iniciales. La conducta de búsqueda de soporte parece aumentar con el daño foliar, pero disminuye con la sequía. Plantas que experimenten simultáneamente daño foliar y sequía intensa tendrán menor probabilidad de encontrar un soporte, resultando en una mayor posibilidad de daño foliar.

Palabras clave: Búsqueda de soporte, sequía, daño foliar, Ipomoea purpurea.

\section{INTRODUCTION}

There is evidence that some climbing plants increase their twining rate (time for a $360^{\circ}$ turn around a support) after leaf damage (Gianoli \& Molina-Montenegro 2005, Atala \& Gianoli 2008). This induced twining can be considered an induced resistance response since it may reduce further damage from ground dwelling herbivores (Hanley et al. 1995, 
Green et al. 1997, Watkinson 1997, Atala \& Gianoli 2008) and may result in associational resistance (González-Teuber $\&$ Gianoli 2008). This response has been reported for some species of Convolvulaceae, including Ipomoea purpurea (L.) Roth (Atala \& Gianoli 2008, 2009a), but it may be found in other plant families. It has been found in Elytropus chilensis an Apocynaceae (Gianoli, unpublished data). The induced twining has been tested by placing the main stem of unsupported climbing plants in direct contact with a physical support and then applying leaf damage (Gianoli \& MolinaMontenegro 2005, Atala \& Gianoli 2008, 2009a). In these studies, successful twining was recorded when a $360^{\circ}$ turn around the support was completed. In nature, twining plants in early stages are seldom in contact with a support and develop a "searching" behavior that is not random and could be related to host volatile perception (Runyon et al. 2006). When climbing plants become structurally unstable they usually produce runners, a specialized stem with elongated internodes and suppressed leaf expansion that searches for support (French 1977, Dubbelden \& Oosterbeek 1995). When a support is found, plants restart leaf production (French 1977, Dubbelden \& Oosterbeek 1995). The finding of suitable support is considered a key ecological process for climbing plants (Putz 1984) and when successful, it results in a greater fitness (Putz 1984, González-Teuber \& Gianoli 2008).

In natural communities, herbivory usually interacts with other stresses that may affect fitness and several plant traits. Drought can co-occur with herbivory in natural communities reducing plant fitness (Lenssen \& De Kroon 2005). A combination of both stresses also limits vegetative growth, reduce leaf area, and decrease plant turgor (Bebber et al. 2002, Levine \& Paige 2004, Gonzáles et al. 2008, Atala \& Gianoli 2009b, Quezada \& Gianoli 2010). Both stresses can affect plant traits independently and, for some traits, synergistically (Atala \& Gianoli 2009b). It has been reported that experimental drought limits, but not suppresses, the induced twining by leaf damage in Ipomoea purpurea (Atala \& Gianoli 2009a). The combined effects of drought and herbivory reduce final plant biomass and fitness in this climbing plant species (Atala \& Gianoli 2009b). Drought and leaf area removal could limit the production of fast growing runners, and hence impair searching support in early ontogenetic stages of climbing plants, when they become biomechanically unstable.

In the present study we tested the effect of drought and leaf damage on the support searching in the twining plant Ipomoea purpurea. We hypothesized that severe drought should increase time for successful twining, particularly combined with leaf damage. This would be due to the low resource availability for rapid growth of runners and low turgence in such conditions. Rapid turgence changes have been implied in the induced twining response (Atala \& Gianoli 2008), but may also be involved in the search for support. We selected I. purpurea because it grows in Mediterranean-type climates in Chile (Matthei 1995), with typical summer drought (Di Castri \& Hajek 1976). In natural populations, I. purpurea commonly shows leaf damage, probably caused by leaf beetles (Atala \& Gianoli, pers. obs.). Thus, this climbing plant may experience a combination of leaf damage and drought in natural conditions.

\section{MATERIALS AND METHODS}

\section{Plant Material}

Commercial seeds of Ipomoea purpurea (L.) Roth (Convolvulaceae) were placed in plastic Petri dishes with damp paper to induce germination. After the first true leaf was visible, plants were transplanted to plastic trays that held 60 plants, each individual plant with $200 \mathrm{ml}$ of commercial soil. When plants were two weeks old, they were transplanted to plastic bags filled with 1.51 of the same potting soil. Plants were randomly assigned to one of six treatments combining two damage levels ( 0 and 50\% defoliation) and three watering regimes (every 2, 10 and 20 days). In every treatment, we watered all plants to field capacity. The sample size was 20 plants for every treatment (120 in total). The resulting treatments were as follows:

$\mathrm{C}-\mathrm{RW}=$ control, undamaged plants and regular watering (every $2 \mathrm{~d}$ )

$\mathrm{H}-\mathrm{RW}=$ simulated herbivory ( $50 \%$ leaf damage $)$ and regular watering

$\mathrm{C}-\mathrm{MD}=$ control plants and moderate drought (watering every $10 \mathrm{~d}$ )

$\mathrm{H}-\mathrm{MD}=$ simulated herbivory and moderate drought

$\mathrm{C}-\mathrm{SD}=$ control plants and severe drought (watering every $20 \mathrm{~d})$

$\mathrm{H}-\mathrm{SD}=$ simulated herbivory and severe drought

We started the watering treatments 14 days after the transplant. Twenty days after the onset of watering regimes, we placed a physical support (plastic stake, $50 \mathrm{~cm}$ tall) $15 \mathrm{~cm}$ away from the unsupported plants. The support was always to the right of the plant tip because the plant circumnutates and twins clockwise. We then applied 50\% defoliation to the plants assigned to the $\mathrm{H}$ - treatments. The damage was done cutting half of the true leaves along the midvein, without cutting it. We recorded the number of plants twining around the support every $12 \mathrm{~h}$ and 7 days after leaf damage all plants were harvested and functional traits were measured. We did not report the $\%$ plant twining after $84 \mathrm{~h}$ because no further change was recorded. A plant was considered twining when a $360^{\circ}$ turn around the support was completed. Plants were separated in stems, leaves and roots and oven-dried for 48 $\mathrm{h}$ at $75^{\circ} \mathrm{C}$.

We estimated relative water content (RWC) as follows: 
RWC $=$ (weight at harvest - dry weight)/ fully hydrated weight. Fully hydrated weight was obtained by submerging plants in water and weighting until constant weight. Relative growth rate (RGR) was calculated as $\mathrm{RGR}=$ (main stem height $(\mathrm{cm})$ at the beginning of the watering treatments (initial size) - main stem height $(\mathrm{cm})$ at the end of the experiment $) /(27 \mathrm{x}$ initial size in $\mathrm{cm}) .27$ corresponds to the number of days since the beginning of the watering treatment.

All leaves were photographed with a digital camera and the leaf area was later measured with image analysis software (SigmaScan pro 5, SPSS, USA). Root/shoot was estimated dividing the dry mass of roots by the dry mass of stems and leaves.

\section{Statistical ANALYSis}

To address differences in searching behavior, we compared the proportion of plants successfully twining (as previously defined) in each treatment every $12 \mathrm{~h}$ with a proportion test (Statistica 8.0, Statsoft Inc., Tulsa, OK, USA). A two-way ANOVA was used to test for the effect of water and leaf damage on all other traits. A Tukey test was used as a posthoc test.

\section{RESULTS}

Leaf damage enhanced the successful climbing onto the support (Fig. 1). Nevertheless, plants subjected to both leaf damage and severe drought showed similar results than undamaged plants (Fig. 1). In the regular watering and moderate drought treatments, $24 \mathrm{~h}$ after launching the experiment, there were a significantly higher proportion of damaged plants climbing onto the support compared to control plants (proportion test, $\mathrm{p}<0.05$; Fig. 1). At the end of the experiment $(84 \mathrm{~h})$ all treatments showed a statistically similar proportion of climbing plants.

Water availability affected all measured traits, and leaf damage affected all of them but RGR (Table I, two-way ANOVA, $\mathrm{p}<0.001$ ). Both RWC (relative water content) and total dry mass were highest in watered and undamaged plants and lowest in damaged plants exposed to severe drought (Table I, Tukey test, $\mathrm{p}<0.05$ ). Drought and leaf damage reduced leaf area, particularly in the DSD treatment (Table I, Tukey test, $\mathrm{p}<0.05)$. The root/shoot ratio increased with drought, and damaged plants under water stress (moderate and severe) showed the highest values (Table I, Tukey test, $\mathrm{p}<0.05)$. Leaf damage affected neither final leaf area nor root/shoot in plants under regular watering (Table I).

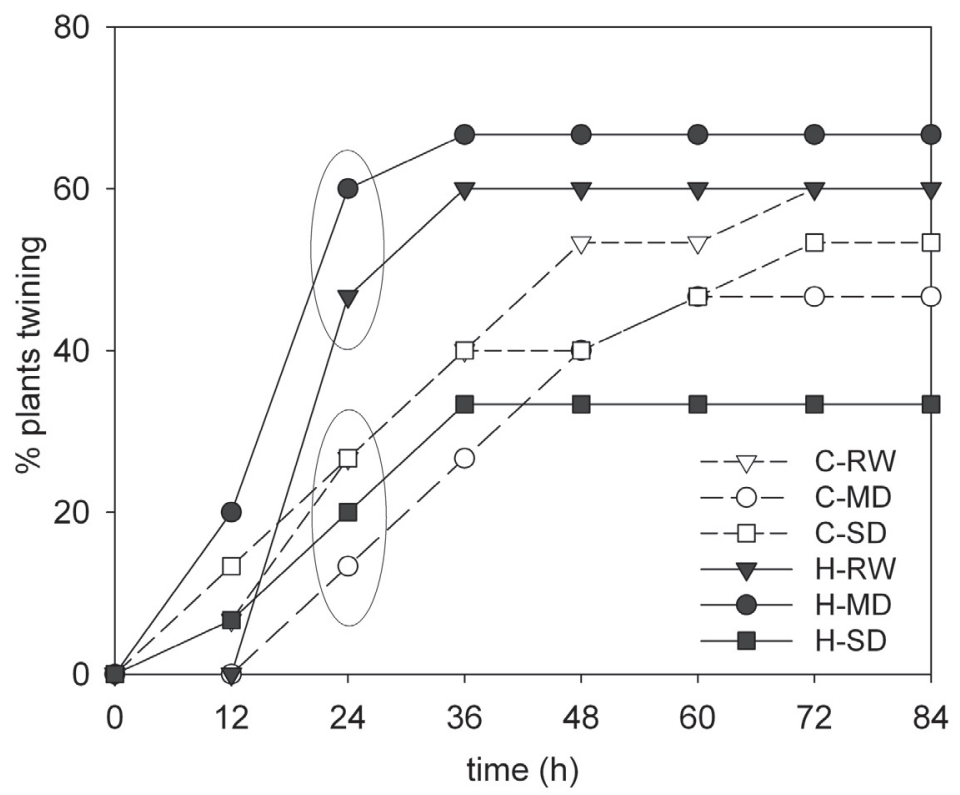

FIGURE 1. Percentage of I. purpurea plants twining around a support over time. The circles show where statistical differences occur between treatments after $24 \mathrm{~h}$ (proportion test, $\mathrm{p}<0.05$ ). $\mathrm{C}-\mathrm{RW}=$ control, undamaged plants and regular watering, $\mathrm{H}-\mathrm{RW}=$ simulated herbivory and regular watering, $\mathrm{C}-\mathrm{MD}=$ control plants and moderate drought, $\mathrm{H}-\mathrm{MD}=$ simulated herbivory and moderate drought, $\mathrm{C}-\mathrm{SD}=\mathrm{control}$ plants and severe drought, $\mathrm{H}-\mathrm{SD}=$ simulated herbivory and severe drought. Sample size $=20$ plants per treatment.

Figura 1. Porcentaje de plantas de I. purpurea enredadas en un soporte en el tiempo. Los círculos muestran diferencias estadísticas entre tratamientos a las $24 \mathrm{~h}$ (test de proporciones $\mathrm{p}<0.05$ ). $\mathrm{C}-\mathrm{RW}=$ plantas control (no dañadas) y riego normal, $\mathrm{H}-\mathrm{RW}=\mathrm{herbivoría} \mathrm{simulada}$ y riego normal, C-MD = plantas control y sequía moderada, $\mathrm{H}-\mathrm{MD}=$ herbivoría simulada y sequía moderada, $\mathrm{C}-\mathrm{SD}=$ plantas control y sequía intensa, $\mathrm{H}-\mathrm{SD}$ = herbivoría simulada y sequía intensa. Se usaron 20 plantas por tratamiento. 


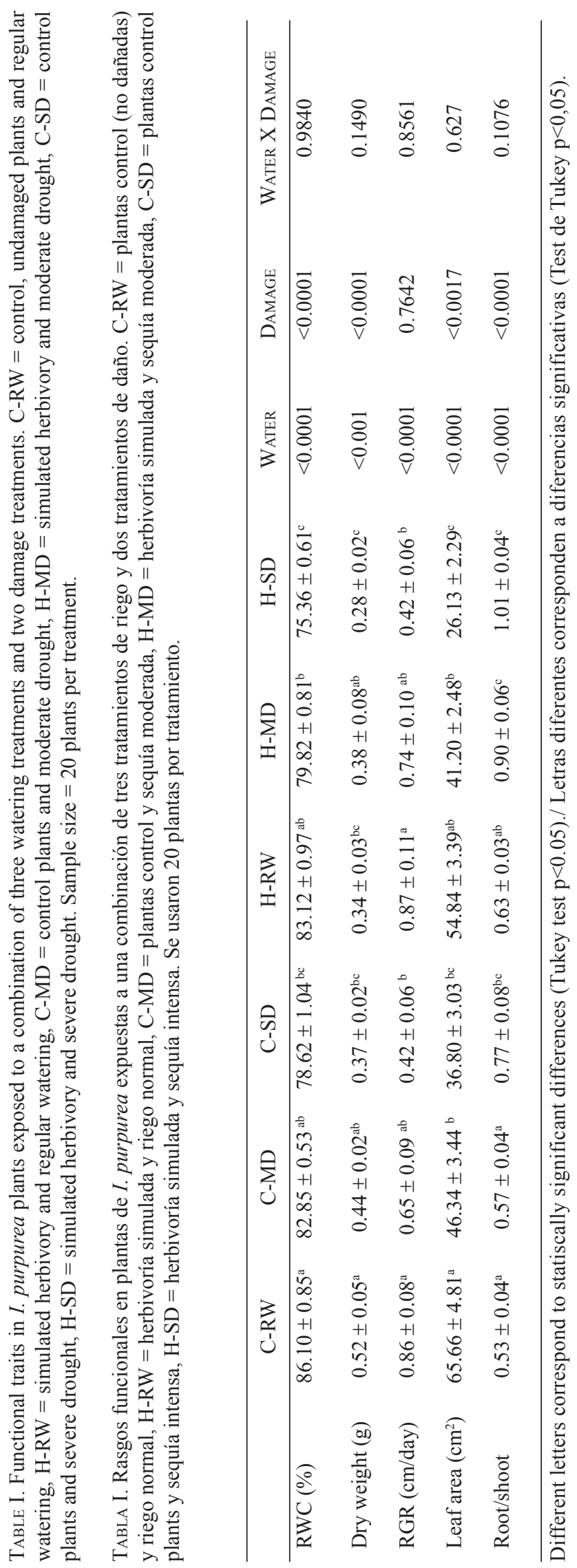




\section{DISCUSSION}

Leaf damage seems to induce the search for support in Ipomoea purpurea. Previous studies on some Convolulaceae species, including I. purpurea, showed that leaf damage can induce twining when the runner was in contact with the support (Gianoli \& Molina-Montenegro 2005, Atala \& Gianoli 2008). Here, we found that leaf damage can also induce the searching behaviour of these plants, but this effect seems to be relatively short-termed. Thus, after 72 $\mathrm{h}$ undamaged plants achieved a twining percentage similar to that of damaged plants. Nevertheless, in the field, this relatively short temporal window of increased success in finding support could be relevant for twining plants, particularly in the early ontogenetic stages, which are more vulnerable to biotic and abiotic stresses (Putz 1984, Gianoli \& Molina-Montenegro 2005).

In severe drought conditions, leaf damage did not enhance support finding. Nevertheless, damaged plants under moderate drought still showed the induction of successful climbing. Ipomoea purpurea grows in central Chile -a Mediterranean climate ecosystem- with typical summer droughts, when insects are abundant and hence plants usually show partial defoliation, possibly by leaf beetles (Atala \& Gianoli, unpublished data). Precipitations in Central Chile are projected to decrease up to $40 \%$ (IPCC 2007). In this climate change context, I. purpurea plants would not be able to tolerate leaf damage (Atala \& Gianoli 2009) and would have reduced success in finding a suitable support. In this scenario, I. purpurea individuals could restrict their local distribution to moister sites.

Plant growth and morphological and biomass allocation traits were affected by drought and damage. Droughtexposed plants had smaller leaves, grew less, and had a higher relative investment on roots, as commonly found in other studies (Hsiao 1973, González et al. 2008, Atala \& Gianoli 2009b). The combination of severe drought and damage inflicted the highest negative impact on plant growth. Damage decreased RWC in all watering treatments, probably due to augmented water loss in the damaged leaves. Leaf damage also increased root/shoot ratio in all watering treatments contrary to previous reports (Tuomi et al. 1994, Strauss \& Agrawal 1999, Huhta et al. 2000). We hypothesize that this is due to the counteractive effect of damage and leaf area loss in drought-exposed plants (Quezada \& Gianoli 2010). RWC was lower in the severe drought treatments. The loss of turgor and reduced growth could account for the lack of succesful climbing induction of damage in plants from this treatment.

The results of the present study show that an abiotic stress, such as drought, can affect the putatively beneficial response to leaf damage of $I$. purpurea in natural (or future) conditions. In nature, plants exposed to herbivory and severe drought could reduce their searching behaviour and thus remain vulnerable to further leaf damage. The ecological impact of this response should be evaluated in the field to confirm some of our findings and to evaluate if natural damage can also elicit the increase in searching in I. purpurea. Field studies are needed to corroborate de ecological relevance of this response in natural populations and the actual magnitude of leaf damage and drought that these plants can experience.

\section{ACKNOWLEDGEMENTS}

Oficina de Investigación y Relaciones Institucionales e Internacionales (OIRII) UdeC Campus Los Ángeles and Departamento de Ciencia y Tecnología Vegetal for funding, Eduardo Navarrete for statistical advice, Guillermo Pereira for the greenhouse space, Pablo Novoa for additional funding, Joaquín Sepúlveda for technical support. The authors would like to thank two anonymous reviewers for their comments that greatly improved this paper.

\section{REFERENCES}

Atala, C. \& E. Gianoli. 2008. Induced twining in Convolvulaceae climbing plants in response to leaf damage. Botany 86 : 595-602.

Atala, C. \& E. Gianoli. 2009a. Drought limits induced twining by leaf damage in the climbing plant Ipomoea purpurea (Convolvulaceae). Gayana Botanica 66(2): 171-176.

Atala, C. \& E. Gianoli. 2009b. Effect of water availability on tolerance of leaf damage in tall morning glory, Ipomoea purpurea. Acta Oecologica 35: 236-242.

Bebber, D., N. Brown \& M. Speight. 2002. Drought and herbivory in understorey Parashorea Kurz (Dipterocarpaceae) seedlings in Borneo. Journal of Tropical Ecology 18: 795804.

Di Castri, F. \& E.R. Hajek. 1976. Bioclimatologia de Chile. Editorial de la Universidad Católica de Chile, Santiago, Chile. 129 pp.

Dubbelden, K.C. \& B. Oosterbeek. 1995. The availability of external support affects allocation patterns and morphology of herbaceous climbing plants. Functional Ecology 9: 628634.

FRENCH, J.C. 1977. Growth relationship of leaves and internodes in viny angiosperms with different modes of attachment. American Journal of Botany 64: 292-304.

Gianoli, E. \& M. GonzÁlez-Teuber. 2005. Environmental heterogeneity and population differentiation in plasticity to drought in Convolvulus chilensis (Convolvulaceae). Evolutionary Ecology 19: 603-613.

Gianoli, E. \& M.A. Molina-Montenegro. 2005. Leaf damage induces twining in a climbing plant. New Phytologist 167: 385-390.

GonzÁles, W.L., M.A. Negritto, L.H. SuÁrez \& E. Gianoli. 2008. Differential induction of glandular and non-glandular trichomes by damage in leaves of Madia sativa under 
contrasting water regimes. Acta Oecologica 33: 128-132.

GonzÁlez-Teuber, M. \& E. Gianoli. 2008. Damage and shade enhance climbing and promote associational resistance in a climbing plant. Journal of Ecology 96: 122-126.

Green, P.T., D.J. O’Dowd \& P.S. LAKE. 1997. Control of seedling recruitment by land crabs in rainforest on a remote oceanic island. Ecology 78: 2474-2486.

Hanley, M.E., M. Fenner \& P.J. Edwards. 1995. An experimental field study of the effects of mollusc grazing on seedling recruitment and survival in grassland. Journal of Ecology 83: 621-627.

Hsiao, T.C. 1973. Plant responses to water stress. Annual Review of Plant Physiology 24: 519-570.

Huhta, A.-P., T. Lennartsson, J. Tuomi, P. Rautio \& K. Laine. 2000. Tolerance of Gentianella campestris in relation to damage intensity: an interplay between apical dominance and herbivory. Evolutionary ecology 14: 373-392.

IPCC. 2007. Intergovernmental Panel of Climate Change. http:// www.ipcc.ch

KARBAN, R. \& I.T. BALDWIN. 1997. Induced Responses to Herbivory. University of Chicago Press, Chicago, IL, USA. 319 pp.

Lenssen, J. P. M. \& H. De Kroon. 2005. Abiotic constraints at the upper boundaries of two Rumex species on a freshwater flooding gradient. Ecology 93: 138-147.

Levine, M.T. \& K.N. Paige. 2004. Direct and indirect effects of drought on compensation following herbivory in scarlet gilia. Ecology 85: 3185-3191.

Matthei, O. 1995. Manual de las malezas que crecen en Chile. Alfabeta, Santiago, Chile. 545 pp.

PuTz, F.E. 1984. The natural-history of lianas on Barro Colorado Island, Panama. Ecology 65: 1713-1724.

Quezada, I.M. \& E. Gianoli. 2010. Counteractive biomass allocation responses to drought and damage in the perennial herb Convolvulus demissus. Austral Ecology 35: 544-548.

Runyon, J.B., M.C. Mescher \& C.M. De Moraes. 2006. Volatile chemical cues guide host location and host selection by parasitic plants. Science 313: 1964-1967.

Strauss, S.Y. \& A.A. Agrawal. 1999. The ecology and evolution of plant tolerance to herbivory. Trends in Ecology and Evolution 14: 179-185.

Tuomi, J., P. Nilsson \& M. Astrom.1994. Plant compensatory responses: bud dormancy as an adaptation to herbivory. Ecology 75: 1429-1436.

Watkinson, A.R. 1997. Plant population dynamics. In: M.J. Crawley (ed.), Plant Ecology, 2nd ed., pp. 359-400. Blackwell Scientific Publications, Oxford, UK.

Recibido: 09.12.10

Aceptado: 13.04.11 